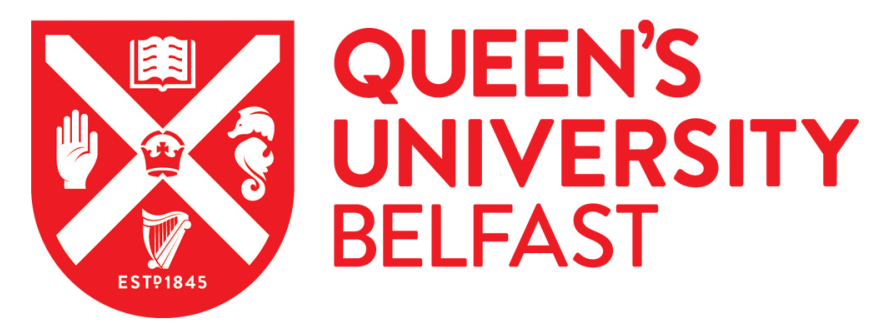

\title{
Entrepreneurial Academics and Academic Entrepreneurs: A Systematic Literature Review
}

Miller, K., Alexander, A., Cunningham, J. A., \& Albats, E. (2018). Entrepreneurial Academics and Academic Entrepreneurs: A Systematic Literature Review. International Journal of Technology Management, 77(1/2/3), 937. https://doi.org/10.1504/IJTM.2018.10012933

Published in:

International Journal of Technology Management

Document Version:

Peer reviewed version

Queen's University Belfast - Research Portal:

Link to publication record in Queen's University Belfast Research Portal

Publisher rights

(C) 2017 Inderscience.

This work is made available online in accordance with the publisher's policies. Please refer to any applicable terms of use of the publisher.

\section{General rights}

Copyright for the publications made accessible via the Queen's University Belfast Research Portal is retained by the author(s) and / or other copyright owners and it is a condition of accessing these publications that users recognise and abide by the legal requirements associated with these rights.

Take down policy

The Research Portal is Queen's institutional repository that provides access to Queen's research output. Every effort has been made to ensure that content in the Research Portal does not infringe any person's rights, or applicable UK laws. If you discover content in the Research Portal that you believe breaches copyright or violates any law, please contact openaccess@qub.ac.uk. 


\title{
Entrepreneurial Academics and Academic Entrepreneurs: A Systematic Literature Review
}

\author{
Kristel Miller* \\ Queen's Management School, Queen's University, Riddel Hall, \\ 185 Stranmillis Road, Belfast, BT95EE, United Kingdom. \\ E-mail: kristel.miller@qub.ac.uk
}

\author{
Allen Alexander \\ Centre for Innovation \& Service Research, University of Exeter Business \\ School, Streatham Court, Exeter, EX4 4ST \\ United Kingdom. \\ E-mail: a.t.alexander@exeter.ac.uk
}

James Cunningham

Newcastle Business School, Northumbria University, Newcastle Upon Type,

NE1 8ST

E-mail: james.cunningham@northumbria.ac.uk

Ekaterina Albats

School of Business and Management, Lappeenranta University of Technology,

Skinnarilankatu 34, 53850, Lappeenranta, Finland.

E-mail: ekaterina.albats@lut.fi 
Distinctions between Entrepreneurial Academic and Academic Entrepreneurs : Accepted for Publication in the International Journal of Technology Management

\begin{abstract}
Universities are now viewed as key economic actors within regions and are central actors in shaping and influencing entrepreneurial ecosystems. This has meant that universities now have to become more entrepreneurial in offerings, outlook and culture. However, a core actor in this process who is often overlooked is the academic. The ability of an academic to effectively transfer knowledge to industry is key to universities achieving their entrepreneurial mission and ambition. This paper explores the changing roles of academics to identify key distinctions between entrepreneurial academics and academic entrepreneurs. This is done through a systematic literature review spanning 25 years drawing on selected high impact journals in innovation, entrepreneurship and higher education studies. We categorise the types of activity that academics typically engage in and identify the motivations and challenges they face. From this we identify two types of academics, the entrepreneurial academic and academic entrepreneur. We posit that there is a need for both types of academics to contribute to the success of the entrepreneurial university and conclude by outlining some avenues for future research.
\end{abstract}

Keywords: University-industry knowledge transfer, entrepreneurial academic, academic entrepreneur, systematic literature review, entrepreneurial university

\title{
1 Introduction
}


Distinctions between Entrepreneurial Academic and Academic Entrepreneurs : Accepted for Publication in the International Journal of Technology Management

Since the emergence of the knowledge economy, there has been increased interest in the role universities have as core conduits of economic development within regions (Smallbone et al., 2015; Guerrero et al., 2016b). The importance of knowledge transfer from universities as a source of new ideas and inventions has positioned universities as key actors in regional and national innovation systems (Abreu and Grinevich, 2013; Guerrero et al., 2016a). In essence, universities are now required to become more entrepreneurial in their organizational outlook and in their offerings. This is not new with Etzkowitz (1983) identifying that an entrepreneurial university should engage more fully with industry and conduct research that has an impact upon society however, the momentum is growing. Recent policy changes have meant that in many regions, university funding is now contingent upon the impact a university can make upon society (Arnkil et al., 2010). Furthermore, the changing needs of society demand closer collaboration between universities and industry to address some of the significant challenges the world faces (Wilson, 2012). All this has resulted in many forward-looking universities reevaluating their core activities and research capabilities resulting in the need for a wide range of modes of university knowledge transfer and business engagement which is responsive to the needs of industry (Bercovitz and Feldman, 2006; Fitzgerald and Cunningham, 2015; Miller et al., 2016). 
Distinctions between Entrepreneurial Academic and Academic Entrepreneurs : Accepted for Publication in the International Journal of Technology Management

Crucial to this change is the academic, whose role as the key actor inevitably determines the success of a university in business engagement activities and therefore the ability for a university to become more entrepreneurial (Guerrero et al., 2015). Traditionally, academics were required to engage in scholarly research and publications, teaching and administration tasks. However, in recent years, there has been an increased emphasis placed on academics winning research funding, becoming more entrepreneurial and having an impact on society, which includes both engagement in technology commercialisation activities and knowledge transfer activities (Miller et al., 2016). According to policy, academic roles (outside teaching and administration) can be grouped into three categories, pure basic research, applied research and technology commercialisation (OECD, 2015) however, within research there is ambiguity over how to define academics who undertake applied research and technology commercialisation. Historically authors have used the term academic entrepreneurship or academic capitalists to encapsulate the wide range of knowledge transfer activities which range from applied research to technology commercialisation (Slaughter and Leslie, 1997). Indeed, the majority of research in this area to date has focused on more formalised academic entrepreneurship, exploring spin out companies, licences and joint ventures (Bozeman, 2000; Rothaermel et al., 2007; Bozeman, 2013; Wright, 2014). However, it has been identified that informal knowledge transfer activities which include consultancy, contract research, 
Distinctions between Entrepreneurial Academic and Academic Entrepreneurs : Accepted for Publication in the International Journal of Technology Management

joint/collaborative research, shared facilities, secondments, training and continued professional development, student placements and student projects can actually produce significant economic and social value for both academics and external partners (Abreu and Grinevich, 2013). There is a growing body of research which identifies the value of informal channels of knowledge transfer (Abreu and Grinevich, 2013; Agrawal and Henderson, 2002; Cohen et al., 2002; D'Este and Patel, 2007) which has been overlooked within both research and practice due to the difficulties of capturing and quantifying the value it offers (Link et al., 2007).

One significant shift in current research is the emergence of a differentiation between the types of entrepreneurial activity. Academics who engage in less formal collaborative knowledge transfer activities have more recently been referred to as an entrepreneurial academics and those engaging in more formal knowledge transfer activities are referred to as being academic entrepreneurs (Alexander et al., 2015). These changes also pose challenges for universities with respect to recruitment and development of academic staff. However, there is a paucity of research that has explored the changing role of academics within entrepreneurial universities despite policy endeavouring to stimulate universities to become more entrepreneurial. Thus to help bridge unity between policy and practice, the purpose of this paper is to critically review literature on academic entrepreneurs and entrepreneurial academics. This will help identify key 
Distinctions between Entrepreneurial Academic and Academic Entrepreneurs : Accepted for Publication in the International Journal of Technology Management

distinctions between the two types of academic; begin to categorise the types of activity that these individuals typically engage in and will identify the motivations and challenges they face. We also aim to identify areas for future research to begin to mature this emerging field.

The contribution of this paper focuses on the important but overlooked role of the academic and this research helps to extend the academic debate on the changing nature of academic job roles whilst more clearly substantiating the need for both academic entrepreneurs and entrepreneurial academics; who contribute to the success of the entrepreneurial university.

In particular we present two summary definitions of the different types of academic which will help improve clarity of future research within the field. We define an entrepreneurial academic as being an 'academic faculty member who adopts an entrepreneurial outlook through seeking opportunities to support their research and teaching objectives by engaging with commercial partners in a range of collaborative and less formal modes of engagement'. In contrast we identify an academic entrepreneur as being an 'academic faculty member who undertakes technology commercialisation, using formal modes of engagement that capitalise on specific market opportunities'. We also identify the types of engagement each type of academic normally adopts and summarise their key motivations and challenges. This will create 
Distinctions between Entrepreneurial Academic and Academic Entrepreneurs :

Accepted for Publication in the International Journal of Technology Management

foundations for new avenues of research and practitioner studies that will help universities to develop processes and interventions to support the changing role of academics, in line with organisational restructuring to help become more entrepreneurial.

The next section of the paper will discuss the systematic literature review (SLR) methodology followed. The core findings will then be presented from which four key themes are delineated. These themes are then synthesised and future research agendas are suggested.

\section{Systematic Literature Review Methodology}

A systematic literature review (SLR) was deemed appropriate in order to sufficiently review a large volume of relatively disparate literature and to give structure to the process to ensure rigor (Tranfield et al., 2003). Following the format for previous SLRs (Henry et al., 2015) a fivestep process was carried out.

Stage one involved a key word search. To help identify the boundaries of the subject, experts were consulted who helped to identify keywords, which would fully encapsulate the entrepreneurial academic and academic entrepreneur phenomena. Initially 8 keywords were identified, namely; 'academic entrepreneur', 'entrepreneurial academic', 'academic 
Distinctions between Entrepreneurial Academic and Academic Entrepreneurs : Accepted for Publication in the International Journal of Technology Management

capitalism', 'academic work', 'academic entrepreneurship', 'academic enterprise', 'academic engagement', 'academic impact' and 'research impact'. However, through discussion with two academic experts, two knowledge transfer senior managers and two technology transfer strategic managers, the key words of academic entrepreneurship and academic enterprise were deemed redundant and would be captured under the term "impact and universities". This left a total of 6 keywords.

Once keywords had been agreed, stage 2 was the journal search. Through consultation with experts in stage 1 , it was identified that peer reviewed articles over the past 25 years would be reviewed (1990-2015) which signals a period in time where academic roles have changed significantly. To ensure academic quality, only journals which were deemed to be recognised leading journals in the fields of higher education, entrepreneurship and innovation were selected. This resulted in the identification of 17 journals shown in appendix 1. Key words were then converted into search strings to conduct an article title search. At this stage the sample size was 273 articles.

The third stage involved scanning and selecting articles for inclusion. This was done through reading the abstracts of identified journals to determine relevance. This reduced the sample 
Distinctions between Entrepreneurial Academic and Academic Entrepreneurs : Accepted for Publication in the International Journal of Technology Management

size to 114 articles. This then led into stage four which involved data extraction. Each of the articles were downloaded and reviewed according to a standardised set proforma ((Tranfield et al. 2003). This proforma formed a raw data repository to be utilised in stage 5. Appendix 2 provides the proforma template and three entry samples. In addition, a handful of 'specific' papers were then included if there were two separate references made to their content within the previously selected articles. This ensured the inclusion of seminal content that might be potentially excluded due to being outside of time window chosen, located in journals from other subjects or arising from important policy documents. This resulted in a total sample size of 129 papers.

The final stage, involved analysing the data from selected articles to identify core themes and future research agendas. To ensure validity and reliability of the coding process, open coding was conducted on each article independently by two of the research team, with any variances discussed amongst the whole research team. This allowed the development of open codes into first and second order themes (O'Kane et al., 2015). 
Distinctions between Entrepreneurial Academic and Academic Entrepreneurs : Accepted for Publication in the International Journal of Technology Management

\subsection{Literature Review}

From our systematic literature review four key themes emerged namely, definitions, knowledge transfer channels, motivations and challenges which we have adopted as a structure for this review. We present the literature in each theme and then summarise the content accordingly allowing us to present guiding definitions, a review framework and relative comparative critique. Conclusions are then drawn and further research avenues are then discussed.

\subsection{Academic Entrepreneurs versus Entrepreneurial Academics - Toward a Consistent} Definition

The term academic entrepreneur was used more frequently within articles than the term entrepreneurial academic with the term entrepreneurial academic only emerging in recent years (Meyer, 2003; Alexander et al., 2015). Several studies did use a broad and encompassing term of 'academic engagement' (e.g. Abreu and Ginevich, 2013; Perkmann et al., 2013), which appears to encapsulate a wide range of both formal and informal knowledge transfer activities which are conducted by academic entrepreneurs and entrepreneurial academics. However, it was evident that there was ambiguity in the definition's used within studies.

3.1.1 Academic Entrepreneurship - the established view 
Distinctions between Entrepreneurial Academic and Academic Entrepreneurs : Accepted for Publication in the International Journal of Technology Management

Within the literature, the general consensus was that the key objective of an academic entrepreneur is to engage in activities which lead to the commercialisation of technology (Rothaermel et al., 2007; Wright, 2014). This is in essence defining them by their actions and this was a common approach, where the activity of an academic entrepreneur can take the form of patents, licences and new venture start-ups (Alexander et al., 2015; Perkmann et al., 2013; Wright et al., 2014). Grimaldi et al. (2011) also refer to academic entrepreneurs engaging in university-industry partnerships however, in their study they note that these partnerships have the sole aim of leading to more effective technology commercialisation and do not cover more informal collaborative activities. It was noted that from the 1990's onwards, coinciding with policy changes demanding universities to become more entrepreneurial, authors began debating the need to revisit the definition of an academic entrepreneur and to more fully understand the changing roles of academics.

\subsubsection{Emergence of the Entrepreneurial Academics}

Several authors discussed the need for a more encompassing definition of academic entrepreneurship due to variations of entrepreneurial activities conducted by academics in different disciplines (Abreu and Grinevich, 2013; Etzkowitz, 2003; Jain et al. 2009;). Indeed, Abreu and Grinevich (2013) note that entrepreneurship involves several activities that go 
Distinctions between Entrepreneurial Academic and Academic Entrepreneurs : Accepted for Publication in the International Journal of Technology Management

beyond the commercialisation of goods and services. These can involve innovatively combining resources to lead to new ways of organising offerings or establishing new processes to deliver them. It also can be used to describe the organised effort put into exploiting opportunities. In a university context, Alexander et al. (2015) note that engaging in entrepreneurship does not always result in an academic becoming an academic entrepreneur. Academics can engage in a wide range of activities which are deemed to be entrepreneurial such as networking or consultancy etc. which Landry et al. (2006) identify are important steps to reaping academic and commercial rewards, not only for the academic engaging in these activities but for the university if effective knowledge management processes are in place. Furthermore, Bains (2005) identify that for certain academics, consultancy can lead to greater financial rewards then engaging in formal commercialisation activities.

Whilst authors argue for more encompassing definitions, it is only in recent years has the term entrepreneurial academic emerged (D'Este and Patel, 2007; Alexander et al.. 2015). It was evident that this was in response to the need for a clearer distinction of academic roles to stress the importance of engagement in more informal knowledge transfer activities. Thus the entrepreneurial academic emerged as a term used to describe academics who engage in wider forms of knowledge transfer which involves personal interactions with industry (Alexander et 
Distinctions between Entrepreneurial Academic and Academic Entrepreneurs : Accepted for Publication in the International Journal of Technology Management

al., 2015; Duberley et al., 2007). Martinelli et al. (2008) identify that an entrepreneurial academic is an 'innovative' faculty member who differs from the archetypical start-up academic entrepreneur. Furthermore, Alexander et al. (2015) identify that an entrepreneurial academic as someone that adopts an entrepreneurial outlook and who readily seeks engagement with industrial partners, often through the less formal modes of engagement, to further their research objectives. This is consistent with the findings of Perkmann et al. (2013) and Meyer (2003) and also is aligned with the Shumpeterian (1960:99) definition of entrepreneurs as “individuals who exploit market opportunity through technical and/or organizational innovation”, where the term 'market opportunity' can be substituted for 'research opportunity'. By synthesising the above inconsistent definitions, we propose a more consistent definition of an entrepreneurial academic as an 'academic faculty member who adopts an entrepreneurial outlook and who supports their research objectives by engaging with commercial partners in a range of collaborative and less formal modes of engagement'.

In contrast, adopting Grimaldi's (2011) and Rothaermel et al. (2007) definition of an academic entrepreneur, and blending this with a Schumpeter view point we posit that an academic entrepreneur is an 'academic faculty member who undertakes technology commercialisation, using formal modes of engagement, that capitalise on specific market opportunities '. 
Distinctions between Entrepreneurial Academic and Academic Entrepreneurs : Accepted for Publication in the International Journal of Technology Management

Overall as universities respond to external economic and social drivers and policy pressure there is a need for them to be more entrepreneurial and this has consequences for the academic role (Martin, 2016). This has led to the need for these definitions to distinguish between a typical academic entrepreneur who is involved in commercialisation activity and those who are involved in more informal and collaborative activities with industry. It is also evident that the difference between the two types of academic can be distinguished from the literature by their modes of engagement across various knowledge transfer channels.

\subsection{Knowledge Transfer Channels}

Throughout the literature reviewed there has been increased interest on how to improve the effectiveness of knowledge transfer from universities to industry. Studies looking at barriers (Bruneel et al., 2010, Galán-Muros and Plewa, 2016) seek to explain the reasons for shortfalls in performance (Rothwell, 1992; Rahm et al., 2000; D'Este and Patel, 2007a; Perkmann et al. 2011) or seek to understand the modes and mechanisms for collaboration (Newey and Shulman 2004, McAdam et al., 2010, Su et al., 2013; Miller et al., 2016) whilst other studies explore strategy perspectives, antecedents, political issues or culture (Arnold et al., 1998, Enkel et al., 2009, Sharifi and Liu, 2010, Petruzzelli, 2011). Within literature, lists have developed which identify the type of activities which constitute university-industry knowledge transfer (Meyer- 
Distinctions between Entrepreneurial Academic and Academic Entrepreneurs : Accepted for Publication in the International Journal of Technology Management

Krahmer and Schmoch, 1998; Schmoch et al., 2000; Schartinger et al., 2002; Bommer and Jalajas, 2004; Holi et al., 2007). Furthermore, various studies categorise these channels according to their degree of formality i.e. formal or informal and their corresponding governance (Schmoch et al., 2000; Alexander and Martin, 2013) or by the type of knowledge flows i.e. tacit or explicit (Alexander and Childe, 2012). Indeed, Alexander et al. (2015) suggest that if channels can be ordered in terms of the formality and governance, then particular channels have the potential to be more attractive and provide greater motivation to the two different types of academics. Figure 1 draws together the findings from various studies (Agrawal and Henderson, 2002; Cohen et al., 2002; D’Este and Patel, 2007; Fini et al., 2010; Link et al., 2007; Ding and Choi, 2011; Alexander et al., 2015) to present an ordering of the various channels of university-industry knowledge transfer linking and the type of academic these channels normally correspond to.

[Insert figure 1 around here]

This ordering of knowledge transfer activity further augments the definitions of the entrepreneurial academics given in section 3.1 by suggesting which channels they may utilise and likewise which channels the varying types of academics may favour. In terms of these channels of knowledge transfer, a major part of the existing literature on academic 
Distinctions between Entrepreneurial Academic and Academic Entrepreneurs : Accepted for Publication in the International Journal of Technology Management

entrepreneurial activity focuses on those activities that occur based around the IP generated within the university system (e.g. patents). However, various authors (Link et al., 2007; D’Este and Patel, 2007) suggest that future research into entrepreneurial academics should explore the softer or more informal entrepreneurial activities (such as consultancy, contract research, informal advice or public lectures) and quantify the value of these activities to prove their potential commercial significance. For example, Fini et al. (2010) found that a large proportion of academic entrepreneurship is happening outside the university IP system. They highlight the value that less informal engagement with industry can provide and suggest the need for a greater emphasis on less formal engagement between academics and industry. Similarly, studies by Agrawal and Henderson (2002), Cohen et al. (2002) D'Este and Patel (2007) and Link et al. (2007) all highlight the importance and significance of informal channels. It was apparent that within literature there has been a convergence that knowledge transfer and business engagement should be considered across the whole spectrum of possible activities. Furthermore, there was explicit evidence that different modes of knowledge transfer align with the respective definitions of entrepreneurial academics vs. academic entrepreneurs as given in section 3.1. 
Distinctions between Entrepreneurial Academic and Academic Entrepreneurs : Accepted for Publication in the International Journal of Technology Management

\subsection{Motivation of academics to engage in knowledge transfer}

Few studies have explored the motivations of individual academics to engage in the diverse range of university-industry knowledge transfer activities (Abreu and Grinevich, 2013; Cunningham et al., 2016a; Guerrero et al., 2014). This is surprising considering academics are the key actor without which knowledge transfer cannot occur. Some studies have explored individual motivations with respect to patenting, licencing and spin outs (Chang et al., 2009; Ding and Choi, 2011). For example, Guerrero and Urbano (2014) found that motivational factors have a direct filter effect on academics' start-up intentions. In particular, it was found that academics' perceived behaviour serves as a knowledge filter, which limits the academics' confidence in their own entrepreneurial skills. Furthermore, Lam (2011) build a conceptual framework of scientists' motivation to commercialize their research results, which include three types of motivation: 'gold' (financial rewards), 'ribbon' (reputational/career rewards) and 'puzzle' (intrinsic satisfaction). Lam (2011) found that there is a diversity of motivations for commercial engagement stating that the majority of the researchers do so for reputational and intrinsic reasons and that financial rewards does not play a significant role in driving commercial engagements. Perkmann et al. (2013) literature review identify that academics engaging in start-up activities often do so for monetary gain. However, Cunningham et al. 
Distinctions between Entrepreneurial Academic and Academic Entrepreneurs : Accepted for Publication in the International Journal of Technology Management

(2015) study of Irish scientists in the principal investigator role found no evidence of motivation for monetary gain.

Very few studies explored the motivations to engage in more informal knowledge transfer activities. An exception was D'este and Patel (2007) who explore the motivations of science and engineering researchers to get involved with knowledge transfer activities. They found that academics engage more frequently with consultancy and contract research, collaborative research or training with industry rather than with commercialisation activities such as patents, licences or spin-out activities. They identify that more informal modes of collaboration with industry is often driven by research related aims. Robinson et al. (2010) conducted exploratory research which identifies that an entrepreneurial academic are those who engage with industry with a view of demonstrating the application of their research to wider society despite often not having contractual obligations. Furthermore, Alexander et al. (2015) presented a list of motivations for entrepreneurial academics which were: fulfilling their research objectives; gaining public recognition for their work; gaining academic esteem for their work; gaining financial reward; making an academic contribution to their field of study; making an academic contribution to society; learning and feedback on applicability of their research. Similarly Cunningham et al. (2016a) identify push (project dependencies and institutional pressures) and 
Distinctions between Entrepreneurial Academic and Academic Entrepreneurs : Accepted for Publication in the International Journal of Technology Management

pull factors (control, career ambition and advancement, personal drive and ambition) that motivate scientists to become publicly funded PIs and hence take the lead on knowledge transfer with industry. Whereas research on the more formal types of entrepreneurial activity (Perkmann and Walsh, 2007; Lam, 2011) suggest that private financial reward is an important motivator for academic entrepreneurs, as is understanding the likely technology trajectory for their inventions. Alexander et al. (2015) differentiate financial reward in terms of personal financial award attributed to commercialisation activities and reward for academics as they create income streams for their research teams or their institutions.

From the SLR it is evident that there is a lack of understanding of motivations for academics to become entrepreneurial. Therefore, whilst it is possible to make tentative conclusions about the relative motivations for being an academic entrepreneur or an entrepreneurial academic more comprehensive research is required into this theme. Whilst understanding motivations are important to understand in establishing the likelihood of academic staff moving towards engaging in entrepreneurial activity, the literature also identified that this shift in activity is not without considerable challenges. 
Distinctions between Entrepreneurial Academic and Academic Entrepreneurs : Accepted for Publication in the International Journal of Technology Management

\subsection{Challenges in Being Entrepreneurial}

Within the literature, challenges impacting the willingness and ability of academics to be entrepreneurial can broadly be categorised into regional level, institutional level and individual level. Each will now be discussed.

\subsubsection{Regional level Challenges}

Whilst regional-level support mechanisms are independent from the university-level support measures, Fini et al. (2010) note that they either compliment or substitute each other. Both Goldfarb and Henrekson (2003) and Jacob et al. (2003) studying Swedish universities transformation found a lack of required flexibility and diversity on both macro-policy level and the university-level. Goldfarb and Henrekson (2003) compare the top-down approach of supporting academic entrepreneurship that prevail in Europe with the more bottom-up approach applied in USA and found the bottom-up approach more successful in stimulating academics to commercialize their research results. Rasmussen et al. (2014) found departmentlevel managerial support (provision of slack time, tangible resources and commercial interaction amongst star researchers) as an important enabler of successful spin-off creation and a source of entrepreneurial competence development. Furthermore, Bercovitz and Feldman (2006) identify that national culture and academic socialisation can impact upon academics willingness to engage in KT activities. 
Distinctions between Entrepreneurial Academic and Academic Entrepreneurs : Accepted for Publication in the International Journal of Technology Management

It was apparent the majority of studies at a regional level largely focused on support for the academic entrepreneur with little discussion of regional support for entrepreneurial academics. However, Bramwell and Wolfe (2008) found that geographical proximity and presence of industrial clusters in the region have been found to be important factors influencing the intensity of academic entrepreneurs' engagements with industry. Furthermore, in case of entrepreneurial academics, policy issues and regional regulations could affect their ability to move between private and public sectors (McDougall and Oviatt, 1996; Dietz and Bozeman, 2005).

\subsubsection{Institutional Level Challenges}

The SLR identified that institutional level challenges largely relate to institutional support, the institutional environment and social norms. Whilst the need for universities to engage more fully with society and become more entrepreneurial has been a reality for many universities for a few decades already, the extent to which universities can embrace these activities is still under debate and is fraught with ethical contradictions between basic sciences supported by governmental funds and applied research serving market needs (Duberley et al., 2007). Indeed, 


\begin{abstract}
Distinctions between Entrepreneurial Academic and Academic Entrepreneurs : Accepted for Publication in the International Journal of Technology Management

it presents uncertainty regarding the specific role both the university and the academic should play within society.
\end{abstract}

Within the literature, it was recognised that whilst academic entrepreneurship goes beyond commercialisation, most institutional initiatives place a greater weighting of resources on commercialisation activities (Siegel et al., 2007; Miller et al., 2014). Abreu and Grinevich (2013) also suggest that this has a detrimental effect on more informal and non-commercial activities which in turn leads to academics feeling a lack of institutional support for engaging in more informal collaborative activities and hence leads to a reticence in engaging in these types of activities.

It was evident that the institutional environment impacts upon the perceived norms regarding engagement in different knowledge transfer activities (Tornatzky et al., 2002). Since the Bayh Dole act, commercialisation activities have been deemed as a legitimate aspect of an academics role (Mowery et al., 2001) however, more informal and collaborative knowledge transfer activities are often seen to be discretionary causing issues with their perceived legitimacy. Findings by Abreu and Grinivich (2013) identify that there is very little institutional interest in informal activities particularly if engaged by academics in the creative arts, humanities and 
Distinctions between Entrepreneurial Academic and Academic Entrepreneurs : Accepted for Publication in the International Journal of Technology Management

social sciences. Indeed, within literature, it was evident that whilst universities are trying to encourage a more entrepreneurial culture, the norms within many universities is that these type of activities are not valued as much as research funding and publications due to the difficulty in quantifying effort versus reward (Rothaermel et al., 2007; Martinelli et al., 2008; Miller et al., 2014)

Several studies identify the need for more institutional support for academics who wish to engage in less formal entrepreneurial activities (Agrawal, 2001; Siegel et al., 2003a; Arvanitis et al., 2008; Cunningham et al., 2015). This support needs to be at both at a department and institutional level. Whilst the academic is an important element, there needs to be supporting institutional frameworks, which stimulate the motivation of academics to engage with industry and the effectiveness of these interactions (Bercovitz and Feldman, 2006). A supportive environment relates to not only career-based reward and recognition but also refers to the resources allocated to enhance engagement with industry (Mitton et al., 2007). Whilst the direct relationship between resource allocation and patent or start up activity is widely reported (Di Gregorio and Shane, 2003; Phan and Siegel, 2006; Wright, 2014), many universities do not allocate resources to help academics engage in more informal knowledge transfer activities. Indeed whilst many universities often have technology transfer offices, the effectiveness of 
Distinctions between Entrepreneurial Academic and Academic Entrepreneurs : Accepted for Publication in the International Journal of Technology Management

these offices in stimulating entrepreneurship within universities is debated (Chapple et al., 2005; Siegel et al., 2007; Muscio, 2010). Studies identify that TTOs are often focused on the processes and metrics and less on providing expert support or helping to develop academics skills to engage in other more informal activities with industry (Ponomariov, 2008; Fini et al., 2010; Abreu and Grinevich, 2013 Fitzgerald and Cunningham, 2015).

Any type of entrepreneurial activity within universities is underpinned by social norms and approval (Clark, 1998; Phan and Siegel, 2006). Indeed, Bercovitz and Feldman (2006) identifies there is significant variation on how university-industry knowledge transfer is rewarded not only across disciplines but also across institutions where institutional policies (governing acceptable publication outputs and research income) makes it difficult for some academics to put time into more informal industry engagement. Moreover, Kenney and Goe (2004) identify that an entrepreneurial culture can overcome institutional disincentives to engage in certain activities. However, as mentioned, many universities are preconditioned to value research and commercialisation activities due to promotional paths often favouring these types of activities. It is widely reported that incentives can help change organisational norms regarding academic engagement with industry (Link and Siegel, 2005; Grimaldi et al. 2011). 
Distinctions between Entrepreneurial Academic and Academic Entrepreneurs : Accepted for Publication in the International Journal of Technology Management

Indeed literature identifies the need for a wider range of knowledge transfer activities to be given recognition within promotional pathways (Tornatzky et al 2002; Siegel et al., 2007).

Finally, the recent study by Leih and Teece (2016) suggest that in addition to simply providing support and enabling legitimacy of entrepreneurial activities among academics, in order to be truly entrepreneurial universities must develop their dynamic capabilities. Particularly they should be sensing opportunities, seizing them by relying on strong university leadership and be able to transform policies, strategies and practices whenever changes call for it (Leih and Teece, 2016).

\subsubsection{Individual Level Challenges}

Individual level challenges have received less empirical attention and focus. However, addressing individual level challenges are fundamental to contributing to more collaborative knowledge transfer activities with industry. Key individual level challenges largely focus on resources. For example De Silva (2015) stress the lack of opportunities and resources academics face when they embark upon entrepreneurial activities. Other authors also comment on the issues of resource or time availability to devote to this activity (Miller et al., 2014; Alexander et al., 2015). 
Distinctions between Entrepreneurial Academic and Academic Entrepreneurs : Accepted for Publication in the International Journal of Technology Management

Another theme that emerged was the key role social influence plays in impacting academics willingness and motivation to engage with industry. Whilst the debate that entrepreneurial behaviour is innate within an individual was noted (O'Shea et al., 2004; Kirby, 2006; D'este and Perkman, 2011) role models can help legitimise and support entrepreneurial activities (Venkataraman, 2004; O'Shea et al., 2005). However, often there is a lack of entrepreneurial role models within universities since as mentioned those activities are often thought to be valued less within internal reward and recognition programmes, stressing the embeddedness of individual and institutional level challenges.

It was evident that there is often a trade-off between exploration (the time and resource required to look for entrepreneurial opportunities) and exploitation (the day-to-day activities that dominate the workload of an academic, such as teaching, research publications, pastoral duties and administration). This trade off suggests that one activity cannot be symbiotic with the other (Radosevich, 1995), however drawing from research from the innovation field and particularly, research on ambidexterity (Raisch and Birkinshaw, 2008) three possible stances could be adopted by an institution wishing to stimulate entrepreneurial activity. The first is to create dual roles within the academic fraternity and this is a model adopted widely in the US, Germany 
Distinctions between Entrepreneurial Academic and Academic Entrepreneurs : Accepted for Publication in the International Journal of Technology Management

and Australia - where professors of professional practice are appointed on equal footing to research-intensive academics (Arnold et al., 1998). Another option is to encourage research teams to have individuals who share their respective skills and cooperate toward a team goal allowing certain members of the team to focus on some aspects of entrepreneurial activity whilst others stay focussed on pure basic research (Sharifi and Liu, 2010). Finally the third option is to try to up skill and motivate each and every academic to become truly ambidextrous and hold a scorecard of outputs that encompass research, teaching, knowledge transfer and entrepreneurial activities; however this will only be effective, according to the literature, if the reward mechanisms reflect this multi-faceted approach (Alexander et al., 2015).

\subsection{Supplementary factors and determinants}

From the literature, other supplementary factors were identified which often impact upon whether an academic decides to engage in certain forms of knowledge transfer with industry. These factors are age, prior experience and gender. With respect to age, Perkmann et al. (2013) reports that the results of studies exploring academic engagement and age are inconclusive, however, seniority was found to positively impact informal collaboration and knowledge transfer with industry due to the provision of more extensive networks and the development of social capital. Aldridge and Audretsch (2011) also identify social capital is a key determent of 
Distinctions between Entrepreneurial Academic and Academic Entrepreneurs : Accepted for Publication in the International Journal of Technology Management

entrepreneurial activity amongst scientists, whereas personal characteristics and human capital were found to have little influence.

Prior experience in engaging with industry was also found to impact upon whether an academic engages in certain knowledge transfer activities (D'este and Patel, 2007). It was also noted that an academics' quality and success within their subject area is said to influence their willingness to engage with industry (Krabel and Meuller, 2009; Fini et al., 2010). This in many ways is synonymous with career stage where a high quality reputation may influence an academics willingness and ability to engage in more informal collaborative activities (Perkmann et al., 2013). However, it should be noted that these factors also appear to be determinants of an academic entrepreneur.

A study by Ding and Choi (2011) presents an interesting comparison of academic entrepreneurs and entrepreneurial academics through the lens of two types of activities, new venture creation and consultancy. They found that commercialisation activities often occur earlier in an academic's career compared to consultancy. Indeed, being an adviser was found to negatively influence an academics willingness to get involved in commercialisation activities. Furthermore, they identify that there is a greater gender gap for females engaging in new 
Distinctions between Entrepreneurial Academic and Academic Entrepreneurs : Accepted for Publication in the International Journal of Technology Management

venture creation compared to consultancy. These findings identify that academics engaging in different types of knowledge transfer often follow divergent paths and are often not a stepping stone to one another. However, there is a need for further research into these areas.

With respect to gender, several studies identified that male academics were more likely to engage in both commercialisation and more informal collaborative activities with industry (Abreu and Grinevich, 2013; Cunningham et al., 2016b; Perkmann et al., 2013). For example Cunningham et al. (2016b) study of Irish scientist in the PI role found that male PI had more commercial experience, invention disclosures and experience of spin-off enterprises, $1 \mathrm{P}$ licensing and contract research than female PIs. Indeed, they note the need for universities to develop entrepreneurship training for more early-career and female academics. Furthermore, studies do note the importance of entrepreneurial role models (Venkataraman, 2004; O'Shea et al., 2005) as key agents in influencing entrepreneurial activities within universities however, this research is largely focused on the development of spin-out companies with a lack of research exploring how role models can impact upon other forms of more informal knowledge transfer. 
Distinctions between Entrepreneurial Academic and Academic Entrepreneurs : Accepted for Publication in the International Journal of Technology Management

Table 1 presents a summary of the findings from the SLR, making distinctions between the key characteristics and challenges faced by academic entrepreneurs versus entrepreneurial academics.

[Insert Table 1 here 
Distinctions between Entrepreneurial Academic and Academic Entrepreneurs : Accepted for Publication in the International Journal of Technology Management

\subsection{Discussion}

One of the aims of this paper was to establish a future research agenda. We now identify and discuss a number of research avenues (summarised in Table 2) which may aid future research exploring the role both entrepreneurial academics and academic entrepreneurs have in supporting universities reach their entrepreneurial missions and how to overcome challenges facing academic-industry engagement and knowledge transfer.

\section{[Insert Table 2 here]}

We first set out to address calls within the literature to provide more consistent definitions and distinctions between entrepreneurial academics and academic entrepreneurs. This distinction reflects the changing nature of the role of academics in the quest for universities to become more entrepreneurial and respond to changing political and societal challenges (D'Este and Perkmann, 2011; Guerrero et al., 2015). From reviewing and interpreting the literature, two definitions have emerged as noted in Table 1. Furthermore Table 2 identifies future research should examine this issue from a discipline, institutional, gender and career perspectives. For example do certain disciplines favour certain types of entrepreneurial academics? What gender 
Distinctions between Entrepreneurial Academic and Academic Entrepreneurs : Accepted for Publication in the International Journal of Technology Management

differences exist between entrepreneurial academics and academic entrepreneurs? Does career stage influence individual academic choice between entrepreneurial academics and academic entrepreneurs? Moreover, examining the entrepreneurial and psychological characteristics of the two types of academics that we have identified is worth further empirical investigation as well as the approaches they take to effectuate their institutional environments to deal with institutional level challenges.

From the literature it was delineated that academic entrepreneurs favour spin-outs, patents and licenses, joint ventures and opportunities to share development facilities with industry as modes of engagement that enable them to commercialise their research. In contrast, entrepreneurial academics are more aligned to networking, joint industry conferences, joint journal publications, joint supervision (of research students) graduate and student placement, secondments, executive education, collaborative research and contracted research and consultancy. It is hoped that by presenting these definitions, future research can more clearly distinguish between different types of academics to avoid ambiguity over what knowledge transfer activities certain academics perform. It is acknowledged that an academic can be both an academic entrepreneur or an entrepreneurial academic or indeed, neither, if they engage in pure basic, non-applied research activities (Alexander et al., 2015). Having recognition of the 
Distinctions between Entrepreneurial Academic and Academic Entrepreneurs : Accepted for Publication in the International Journal of Technology Management

different roles academics play with regards their engagement in knowledge transfer with industry provides the first step in recognising the importance of less formal models of engagement to achieve a universities mission of becoming entrepreneurial (Link et al., 2007; D'este and Perkmann, 2011; Perkmann et al., 2013). Furthermore, this helps provide clear distinctions between the different engagement activities academics have with industry. Future studies should attempt to capture the value and impact less formal university knowledge transfer activities have for industry and wider society (Abreu and Grinevich, 2013). Further studies examining value creation and destruction of both types of academics in entrepreneurial universities is warranted as well as what are the particular institutional and individual value drivers that shape knowledge transfer. This will be beneficial for both academics and knowledge transfer managers through justifying the need for resources to be invested in a wider range of knowledge transfer activities beyond technology commercialisation. Further research can build on existing studies in the form of investment in entrepreneurship training, particularly for more junior and female academics (Clarysse et al., 2011; Abreu and Grinevich, 2013; Gately and Cunningham, 2014), the recruitment of boundary spanning individuals to aid engagement between academics and industry (Siegel et al., 2003; Miller et al., 2016), the identification and reward of entrepreneurial roles models within departments (O'Shea et al., 2005; Venkataraman, 2004) and the allocation of time and recognition to academics engaging 
Distinctions between Entrepreneurial Academic and Academic Entrepreneurs : Accepted for Publication in the International Journal of Technology Management

in different types of entrepreneurial knowledge transfer activities (Perkmann et al., 2013; Alexander et al., 2015; Cunningham et al, 2016c). Advancing this research agenda around these issues will help us better understand discipline, departmental and institutional norms and understand how legitimacy of engagement manifests itself in the wide spectrum of knowledge transfer activities necessary for a university to be truly entrepreneurial. Future research can then explore the impact of the implementation of these initiatives have on knowledge transfer activities.

Within the literature, there was evidence that entrepreneurial academics are motivated to some extent in different ways to academic entrepreneurs. Whilst results do not appear to be conclusive, there was consensus that academic entrepreneurs are motived by opportunities to further their research objectives (Rothaermel et al., 2007; Wright 2014), whilst understanding the validity of their research questions and chosen approach. They are also motivated by gaining peer recognition and esteem, by creating a contribution to their chosen field and also by making a contribution to the wider societal issues and challenges (Cunningham et al. 2016a; D'Este and Perkmann, 2011). Income is also a motivational factor, but when realised for their home institution rather than personally (Alexander et al., 2015). In contrast, academic entrepreneurs are motived by understanding the commercial lifecycle of their research outputs, 
Distinctions between Entrepreneurial Academic and Academic Entrepreneurs : Accepted for Publication in the International Journal of Technology Management

by public recognition and by realising sources of supplementary private income (Meyer, 2003; Perkmann et al., 2013). However, there is ambiguity over certain motivational factors calling for the need for more research to more clearly distinguish the motivational factors and institutional conditions necessary to become an entrepreneurial academic. Such research could address this issue from a discipline, gender and or career perspectives. Such studies would provide further support to university managers to align reward and recognition processes to help stimulate more academics to become entrepreneurial. There is also a need to explore if performance management can help encourage entrepreneurship within universities.

Finally, the literature suggests that these academic groups face a range of challenges. These challenges are at a policy level, at an institutional level or at an individual level. What is not evident from the literature is a clear differentiation of the relative bias toward some challenges being more prevalent for one type of academic. At a policy level, the challenge of shifting toward impactful research, whilst stimulating economic growth arising from the transfer of knowledge (D'Este and Patel, 2007) is equally as challenging for each group however, it is recognised that the type of outputs created by academic entrepreneurs are currently easier to measure (Holi et al., 2008). At an organisational level the same issues of measurement are prevalent, but challenges are identified in terms of promotion and career progression equally 
Distinctions between Entrepreneurial Academic and Academic Entrepreneurs : Accepted for Publication in the International Journal of Technology Management

for both types of academic where even academic entrepreneurs need to demonstrate their impact beyond new venture creation (Meyer, 2003; Jain et al., 2009; Clarysse et al., 2011). There is also the challenge of overcoming organisational and departmental level norms and legitimacy of being an entrepreneurial academic (Alexander et al., 2015; Cunningham et al., 2014; Haeussler and Colyvas, 2011). Furthermore there is a need to explore how these norms and perceptions of legitimacy vary across universities of different types (Bercovitz and Feldman, 2006). There is a need to explore what policies may help the perceived legitimacy of engaging in less formal knowledge transfer activities. Furthermore, there is a need for research on how actors (such as Deans, Heads of Department etc.) really influence the legitimisation of these activities within entrepreneurial universities among both types of academics.

At a personal level, the main challenges identified is the ability to focus on research and teaching outputs whilst engaging in the entrepreneurial activities. Whilst this challenge is not necessarily new, with various authors debating the publish versus patent debate (Rothaermel et al., 2007) and investing time and resources into informal knowledge transfer activities where the value and impact is harder to measure or may take a long lead time to measure. All this presents new challenges for academics seeking the best route to pursue career progression when under pressure to make an impact to society (see Cunningham et al. 2015). However, there is 
Distinctions between Entrepreneurial Academic and Academic Entrepreneurs : Accepted for Publication in the International Journal of Technology Management

acknowledgement that for entrepreneurial academics, developing industry relationships may help support their research objectives thus attributing to wider organisational targets. There is an agreement that support mechanisms should be put in place as should reward mechanisms to create an environment where the culture is geared toward entrepreneurial academic outputs (Etzkowitz 2003; O’Shea et al., 2007; Bramwell and Wolfe, 2008). This issue opens up further research avenues in how do both types of academic approach the tensions and dilemmas they face and what factors (such as formal and informal rewards) really influence both types of academics. Furthermore, there is a need to identify what coping strategies and networks, both formal and informal these types of academic utilize.

\subsection{Conclusion}

Over the past 25 years, universities have faced significant challenges as they have had to rethink their purpose, role, organisational processes and scope to more fully meet the needs of society and more fully make an impact on society (Etzkowtz, 2004; Miller et al., 2014). Universities are now expected to be both innovative and entrepreneurial which demands both institutional and cultural change to embrace a much wider range of knowledge transfer activities to help achieve this mission (Etzkowitz, 2003). A core actor within an entrepreneurial university is the

academic however, to date there is a lack of research which has explored the motivations of 
Distinctions between Entrepreneurial Academic and Academic Entrepreneurs : Accepted for Publication in the International Journal of Technology Management

academics to engage in a wide range of knowledge transfer activities or which has explored the changed to their respective job roles (Jain et al., 2009; D'Este and Perkmann, 2011; Guerrero et al., 2015). This research helped fill this gap by providing a more nuanced understanding of the changing role of academics and to identify core differences and distinctions of academic entrepreneurs and entrepreneurial academics. In doing so we drew on journal articles from top quality journals between the years 1990-2015 were critiqued to help identify the core motivations and challenges of entrepreneurial academics and academic entrepreneurs and led to suggestions for future research.

This SLR makes several contributions. First, it helps overcome ambiguity and inconsistency in prior studies regarding what constitutes an academic entrepreneur (Rothaermel et al., 2007; Wright, 2014) by more clearly defining the distinction between an academic entrepreneur and entrepreneurial academic through focusing on their actions and modes of engagement with industry. These more nuanced definitions will improve comparability of future studies (Bercovitz and Feldman, 2006). Second, the clear distinction outlined between different modes of engagement between academics and industry reflects the need to more fully acknowledge the value of a wide range of knowledge transfer activities, particularly less formal knowledge transfer activities between academics. The distinction also helps identify the value of varying 
Distinctions between Entrepreneurial Academic and Academic Entrepreneurs : Accepted for Publication in the International Journal of Technology Management

types of academics in helping achieve the entrepreneurial mission of a university. Third, this SLR presents several suggestions for future research which will not only assist researchers but have practical implications in helping universities more fully understand the motivations and challenges of entrepreneurial academics in comparison to academic entrepreneurs so that interventions can be implemented to help them to improve the effectiveness of their knowledge transfer activities.

This research has a few limitations. First, the papers reviewed span 25 years however, it is acknowledged that evidence of entrepreneurial activities within universities precedes 1990 . Furthermore, the authors targeted the top innovation, entrepreneurship and higher education journals however, it is acknowledged that this may not have fully captured the wide range of papers published within this topic however, the rigorous SLR followed ensured that the key seminal articles within this research area was captured. Finally, we acknowledge that is some aspects of the review, we have been over reliant on specific articles. However, since the field is immature and in an embryonic state and lacks vast volumes of research, particularly focussing on specific aspect or details of the process, then this is to be expected. These articles will become more evident as the field matures and hopefully, this systematic review of the 


\begin{abstract}
Distinctions between Entrepreneurial Academic and Academic Entrepreneurs : Accepted for Publication in the International Journal of Technology Management
\end{abstract}

literature thus far provides a foundation and motivation on which to build future research endeavours.

\title{
Acknowledgements
}

The authors wish to acknowledge the constructive suggestions and feedback of two anonymous and the research assistance of Chris Young. James Cunningham wishes to acknowledge the funding support of Science Foundation Ireland (SFI) and co-funded under the European Regional Development Fund under Grant Number 13/RC/2073.

\section{References}

ABREU, M. \& GRINEVICH, V. 2013. The nature of academic entrepreneurship in the UK: Widening the focus on entrepreneurial activities. Research Policy, 42, 408-422.

AGRAWAL, A.K., 2001. University-to-industry knowledge transfer: Literature review and unanswered questions. International Journal of management reviews, 3(4), pp.285302.

AGRAWAL, A. \& HENDERSON, R. 2002. Putting patents in context: Exploring knowledge transfer from MIT. Management science, 48, 44-60.

ALDRIDGE, T. T. \& AUDRETSCH, D. 2011. The Bayh-Dole act and scientist entrepreneurship. Research policy, 40, 1058-1067.

ALEXANDER, A. T. \& CHILDE, S. J. 2012. A framework for the transfer of knowledge between universities and industry. In: FRICK, J. (ed.) Advances in Information \& Comunication Technology. New York: Springer.

ALEXANDER, A. T. \& CHILDE, S. J. 2013. Innovation: a knowledge transfer perspective. Production Planning \& Control, 24, 208-225.

ALEXANDER, A. T. \& MARTIN, D. P. 2013. Intermediaries for open innovation: A competence-based comparison of knowledge transfer offices practices. Technological Forecasting and Social Change, 80, 38-49.

ALEXANDER, A. T., MILLER, K. \& FIELDING, S., N. (2015) Open for Business: Universities, Entrepreneurial Academics \& Open Innovation. In: CONN, S., 
Distinctions between Entrepreneurial Academic and Academic Entrepreneurs :

Accepted for Publication in the International Journal of Technology Management

BITRAN, I. \& HUIZINGH, E. K. R. E., eds. XXVI ISPIM International Conference Shaping the Frontiers of Innovation Management, 14-17 June, Budapest, Hungary. Wiley \& Sons.

ARNKIL, R., JÄRVENSIVU, A., KOSKI, P. \& PIIRAINEN, T. 2010. Exploring the quadruple helix. Report of Quadruple Helix Research for the CLIQ Project. Tampere: Work Research Centre, University of Tampere.

ARNOLD, E., RUSH, H., BESSANT, J. \& HOBDAY, M. 1998. Strategic Planning in Research and Technology Institutes. $R \& D$ Management, 28, 89-100.

ARVANITIS, S., KUBLI, U. \& WOERTER, M. 2008. University-industry knowledge and technology transfer in Switzerland: What university scientists think about cooperation with private enterprises. Research Policy, 37, 1865-1883.

BAINS, W. 2005. How academics can make (extra) money out of their science. Journal of Commercial Biotechnology, 11, 353-363.

BERCOVITZ, J. \& FELDMAN, M. 2006. Entpreprenerial universities and technology transfer: A conceptual framework for understanding knowledge-based economic development. The Journal of Technology Transfer, 31, 175-188.

BOMMER, M. \& JALAJAS, D. 2004. Innovation sources of large and small technologybased firms. IEEE Transactions in Engineering Management, 51, 13-17.

BOZEMAN, B. 2000. Technology transfer and public policy: a review of research and theory. Research policy, 29, 627-655.

BOZEMAN, B., FAY, D. \& SLADE, C. 2013. Research collaboration in universities and academic entrepreneurship: the-state-of-the-art. . The Journal of Technology Transfer, 38, 1-67.

BRAMWELL, A. \& WOLFE, D. A. 2008. Universities and regional economic development: The entrepreneurial University of Waterloo. Research Policy, 37, 1175-1187.

BRENNAN, M. C., \& MCGOWAN, P. 2006. Academic entrepreneurship: an exploratory case study. International Journal of Entrepreneurial Behavior \& Research, 12, 144164.

BRUNEEL, J., D'ESTE, P. \& SALTER, A. 2010. Investigating the factors that diminish the barriers to university-industry collaboration. Research Policy, 39, 858-868.

CHAPPLE, W., LOCKETT, A., SIEGEL, D. \& WRIGHT, M. 2005. Assessing the relative performance of UK university technology transfer offices: parametric and nonparametric evidence. Research Policy, 34, 369-384.

CHANG, Y. C., YANG, P.Y, \& CHEN, M-H. 2009. The determinants of academic research performance: Towards and organisational ambidexterity perspective. Research Policy, 38, 936-946. 
Distinctions between Entrepreneurial Academic and Academic Entrepreneurs : Accepted for Publication in the International Journal of Technology Management

CLARK, B. R. 1998. The entrepreneurial university: Demand and response 1. Tertiary Education \& Management, 4, 5-16.

CLARYSSE, B., TARTARI, V. \& SALTER, A. 2011. The impact of entrepreneurial capacity, experience and organisational support on academic entrepreneurship. Research Policy, 40, 1084-1093.

COHEN, W. M., NELSON, R. R. \& WALSH, J. P. 2002. Links and impacts: the influence of public research on industrial R\&D. Management science, 48, 1-23.

CUNNINGHAM, J. A., MANGEMATIN, V., O'KANE, C., \& O'REILLY, P. 2016a. At the frontiers of scientific advancement: the factors that influence scientists to become or choose to become publicly funded principal investigators. The Journal of Technology Transfer, 41(4),778-797.

CUNNINGHAM, J.A., O'REILLY, P., DOLAN, B., O'KANE, C., AND MANGEMATIN, V. 2016b. Female Publicly Funded Principal Investigators, Gender Issues in Entrepreneurship in Al Link, Edward Elgar. (forthcoming)

CUNNINGHAM, J.A., O'REILLY, P., DOLAN, B., \& MANGEMATIN, V. 2016c. Publicly Funded Principal Investigators Allocation of Time for Public Sector Entrepreneurship Activities, Economia e Politica Industriale, (forthcoming).

CUNNINGHAM, J. A., O'REILLY, P., O'KANE, C., \& MANGEMATIN, V. 2015. Managerial challenges of publicly funded principal investigators. International Journal of Technology Management, 68(3-4), 176-202.

D'ESTE, D. \& PATEL, P. 2007. University-industry linkages in the UK: What are the factors underlying the variety of interactions with industry. Research Policy, 36, 1295-1313.

D'ESTE, P. \& NEELY, A. 2007. Science and technology in the UK: 2006 census. Advanced Institute of Management (AIM) Research.

D'ESTE, P. \& PATEL, P. 2007. University-industry linkages in the UK: What are the factors underlying the variety of interactions with industry? Research policy, 36, 1295-1313.

D'ESTE, P. \& PERKMANN, M. 2011. Why do academics engage with industry? The entrepreneurial university and individual motivations. The Journal of Technology Transfer, 36, 316-339.

DE SILVA, M. 2015. Academic entrepreneurship and traditional academic duties: synergy or rivalry? Studies in Higher Education, 1-15.

DIETZ, J.S. \& BOZEMAN, B. 2005. Academic careers, patents and productivity: industry experience as scientific and technical human capital. Research Policy, 34, 349-367.

DI GREGORIO, D. \& SHANE, S. 2003. Why do some universities generate more start-ups than others? Research policy, 32, 209-227. 
Distinctions between Entrepreneurial Academic and Academic Entrepreneurs :

Accepted for Publication in the International Journal of Technology Management

DING, W. \& CHOI, E. 2011. Divergent paths to commercial science: A comparison of scientists' founding and advising activities. Research policy, 40, 69-80.

DUBERLEY, J., COHEN, L. \& LEESON, E. 2007. Entrepreneurial academics: developing scientific careers in changing university settings. Higher Education Quarterly, 61, 479-497.

ENKEL, E., GASSMANN, O. \& CHESBROUGH, H. 2009. Open R\&D and open innovation: exploring the phenomenon. $R \& D$ Management, 39, 311-316.

ETZKOWITZ, H. 1983. Entrepreneurial scientists and entrepreneurial universities in American academic science. Minerva, 21, 198-233.

ETZKOWITZ, H. 2003. Research groups as 'quasi-firms': the invention of the entrepreneurial university. Research policy, 32, 109-121.

ETZKOWITZ, H. 2004. The evolution of the entrepreneurial university. International Journal of Technology and Globalisation, 1, 64-77.

FITZGERALD, C., \& CUNNINGHAM, J. A. 2015. Inside the university technology transfer office: Mission statement analysis. The Journal of Technology Transfer, 1-12. doi:10.1007/s10961-015-9419-6.

FINI, R., LACETERA, N. \& SHANE, S. 2010. Inside or outside the IP system? Business creation in academia. Research Policy, 39, 1060-1069.

FRANKLIN, S. J., WRIGHT, M., \& LOCKETT, A. (2001). Academic and surrogate entrepreneurs in university spin-out companies. The Journal of Technology Transfer, 26(1-2), 127-141.

GATELY, C., \& CUNNINGHAM, J.A. 2014. Building intellectual capital in incubated technology firms. Journal of Intellectual Capital, 15(4), 516-536.

GALÁN-MUROS, V. \& PLEWA, C. 2016. What drives and inhibits university-business cooperation in Europe? A comprehensive assessement. $R \& D$ Management, 46, 369382.

GOLDFARB, B. \& HENREKSON, M. 2003. Bottom-up versus top-down policies towards the commercialization of university intellectual property. Research policy, 32, 639658.

GRIMALDI, R., KENNEY, M., SIEGEL, D. S. \& WRIGHT, M. 2011. 30 years after BayhDole: Reassessing academic entrepreneurship. Research Policy, 40, 1045-1057.

GUERRERO, M., URBANO, D., \& FAYOLLE, A. 2016a. Entrepreneurial activity and regional competitiveness: evidence from European entrepreneurial universities. The Journal of Technology Transfer, 41(1), 105-131. 
Distinctions between Entrepreneurial Academic and Academic Entrepreneurs :

Accepted for Publication in the International Journal of Technology Management

GUERRERO, M., URBANO, D., FAYOLLE, A., KLOFSTEN, M., \& MIAN, S. $2016 \mathrm{~b}$. Entrepreneurial universities: emerging models in the new social and economic landscape. Small Business Economics, 1-13. DOI 10.1007/s11187-016-9755-4.

GUERRERO, M., CUNNINGHAM, J. A. \& URBANO, D. 2015. Economic impact of entrepreneurial universities' activities: An exploratory study of the United Kingdom. Research Policy, 44, 748-764.

GUERRERO, M. \& URBANO, D. 2014. Academics' start-up intentions and knowledge filters: an individual perspective of the knowledge spillover theory of entrepreneurship. Small Business Economics, 43, 57-74.

GUERRERO, M., URBANO, D., CUNNINGHAM, J. \& ORGAN, D. 2014. Entrepreneurial universities in two European regions: A case study comparison. The journal of technology Transfer, 39, 415-434.

HAEUSSLER, C. \& COLYVAS, J. A. 2011. Breaking the ivory tower: academic entrepreneurship in the life sciences in UK and Germany. Research Policy, 40, 41-54.

HENRY, C., FOSS, L. \& AHL, H. 2015. Gender and entrepreneurship research: A review of methodological approaches. International Small Business Journal, 0266242614549779.

HOLI, M., FRANKLIN, R., HUGO, E. \& LAPINSKI, J. 2007. An analysis of UK university technology and knowledge transfer activities. 1, 1-2.

HOLI, M., T, WICKRAMASINGHE, R. \& VAN LEEUWEN, M. 2008. Metrics for the evaluation of knowledge transfer activites at Universities. London: Library House.

JACOB, M., LUNDQVIST, M. \& HELLSMARK, H. 2003. Entrepreneurial transformations in the Swedish University system: the case of Chalmers University of Technology. Research Policy, 32, 1555-1568.

JAIN, S., GEORGE, G. \& MALTARICH, M. 2009. Academics or entrepreneurs? Investigating role identity modification of university scientists involved in commercialization activity. Research policy, 38, 922-935.

KENNEY, M. \& GOE, W. R. 2004. The role of social embeddedness in professorial entrepreneurship: a comparison of electrical engineering and computer science at UC Berkeley and Stanford. Research Policy, 33, 691-707.

KIRBY, D.A. 2006. Creating entrepreneurial unversities in the UK: Applying entrepreneurship theory to practice. Journal of Technology Transfer, 31, 599-603.

KRABEL, S. \& MEULLER, P. 2009. What drives scientists to start their own company? An empirical investigation of the Max Panck Society Scientists. Research Policy, 38, 947-956. 
Distinctions between Entrepreneurial Academic and Academic Entrepreneurs :

Accepted for Publication in the International Journal of Technology Management

LAM, A. 2011. What motivates academic scientists to engage in research commercialization: 'Gold', 'ribbon'or 'puzzle'? Research Policy, 40, 1354-1368.

LANDRY, R., AMARA, N. \& RHERRAD, I. 2006. Why are some university researchers more likely to create spin-offs than others? Evidence from Canadian universities. Research Policy, 35, 1599-1615.

LEIH, S. \& TEECE, D., 2016. Campus Leadership and the Entrepreneurial University: A Dynamic Capabilities Perspective. Academy of Management Perspectives 3 (2) May 2016, pp. 182-210

LIBAERS, D. \& WANG, T., 2012. Foreign-born academic scientists: entrepreneurial academics or academic entrepreneurs?. R\&D Management,42(3), pp.254-272.

LINK, A. N. \& SIEGEL, D. S. 2005. University-based technology initiatives: Quantitative and qualitative evidence. Research Policy, 34, 253-257.

LINK, A. N., SIEGEL, D. S. \& BOZEMAN, B. 2007. An empirical analysis of the propensity of academics to engage in informal university technology transfer. Industrial and corporate change, 16, 641-655.

MARTIN, B. 2016. What is Happening to our Universities?. Accessed $9^{\text {th }}$ August 2016 http://papers.ssrn.com/sol3/papers.cfm?abstract_id=2745139

MARTINELLI, A., MEYER, M. \& VON TUNZELMANN, N. 2008. Becoming an entrepreneurial university? A case study of knowledge exchange relationships and faculty attitudes in a medium-sized, research-oriented university. The Journal of Technology Transfer, 33, 259-283.

MCADAM, M., MCADAM, R., GALBRAITH, B. \& MILLER, K. 2010. An exploratory study of Principal Investigator roles in UK university Proof-of-Concept processes: an Absorptive Capacity perspective. R\&D Management, 40, 455-473.

MCDOUGALL, P.P. and OVIATT, B.M. 1996. New venture internationalisation, strategic change and performance: A follow up study. Journal of Business Venturing, 11, 2340.

MEYER-KRAHMER, F. \& SCHMOCH, U. 1998. Science-based Technologies: UniversityIndustry interactions in four fields Research Policy, 27, 835-851.

MEYER, M. 2003. Academic entrepreneurs or entrepreneurial academics? Research-based ventures and public support mechanisms. $R \& D$ Management, 33, 107-115.

MILLER, K., MCADAM, M. \& MCADAM, R. 2014. The changing university business model: a stakeholder perspective. $R$ and D Management, 44, 265-287.

MILLER, K., MCADAM, R., MOFFETT, S., ALEXANDER, A. \& PUTHUSSERRY, P. 2016. Knowledge transfer in university quadruple helix ecosystems: an absorptive capacity perspective. $R \& D$ Management, 46, 383-399. 
Distinctions between Entrepreneurial Academic and Academic Entrepreneurs :

Accepted for Publication in the International Journal of Technology Management

MITTON, C., ADAIR, C., MCKENZIE, E., PATTEN, S. \& PERRY, B. 2007. Knowledge Transfer \& Exchange: Review and synthesis of the literature. The Milbank Quarterly, 85, 729-768.

MOLAS-GALLART, J., SALTER, A., PATEL, P., SCOTT, A. \& DURAN, X., 2002. Measuring third stream activities. Final report to the Russell Group of Universities. Brighton: SPRU, University of Sussex.

MOWERY, D.C., NELSON, R.R., SAMPAT, B.N. \& ZIEDONIS, A.A. 2001. The growth of patenting and licensing by U.S. universities: an assessment of the effects of the Bayh Dole act of 1980. Research Policy, 30, 99-119.

MUSCIO, A. 2010. What drives the university use of technology transfer offices? Evidence from Italy. The Journal of Technology Transfer, 35, 181-202.

NEWEY, L. R. \& SHULMAN, A. D. 2004. Systemic absorptive capacity: creating early-tomarket returns through $\mathrm{R} \& \mathrm{D}$ alliances. $R \& D$ Management, 34, 495-504.

O'SHEA, R., ALLEN, T.J. \& O'GORMAN, C. 2004. Universities and technology transfer: A review of academic entrepreneurship literature. Irish Journal of Management, 25, 1129.

O'SHEA, R., ALLEN, T.J., CHEV ALIER, A. \& ROCHE, F. 2005. Entrepreneurial orientation, technology transfer and spinoff performance of US universities. Research Policy, 34, 994-1009.

O'SHEA, R. P., ALLEN, T. J., MORSE, K. P., O'GORMAN, C. \& ROCHE, F. 2007. Delineating the anatomy of an entrepreneurial university: the Massachusetts Institute of Technology experience. $R \& d$ Management, 37, 1-16.

O'KANE, C., MANGEMATIN, V., GEOGHEGAN, W. \& FITZGERALD, C. 2015. University technology transfer offices: The search for identity to build legitimacy. Research Policy, 44, 421-437.

OECD 2015. Frascati Manual 2015, OECD Publishing.

PERKMANN, M., NEELY, A. \& WALSH, K. 2011. How should firms evaluate success in university-industry alliances? A performance measurement system. $R \& D$ Management, 41, 202-216.

PERKMANN, M., TARTARI, V., MCKELVEY, M., AUTIO, E., BROSTROM, A., D'ESTE, P., FINI, R., GEUNA, A., GRIMALDI, R., HUGHES, A., KRABEL, S., KITSON, M., LLERENA, P., LISSONI, F., SALTER, A. \& SOBRERO, M. 2013. Academic engagement and commercialisation: A review of the literature on university-industry relations. Research Policy, 42, 423-442. 
Distinctions between Entrepreneurial Academic and Academic Entrepreneurs :

Accepted for Publication in the International Journal of Technology Management

PERKMANN, M. \& WALSH, K. 2007. University-industry relationships and open innovation: Towards a research agenda. International Journal of Management Reviews, 9, 259-280.

PETRUZZELLI, A. M. 2011. The impact of technological relatedness, prior ties, and geographical distance on university-industry collaborations: A joint-patent analysis. Technovation, 31, 309-319.

PHAN, P. \& SIEGEL, D. S. 2006. The effectiveness of university technology transfer. Foundations and Trends in Entrepreneurship, 2.

PONOMARIOV, B. L. 2008. Effects of university characteristics on scientists' interactions with the private sector: an exploratory assessment. The Journal of Technology Transfer, 33, 485-503.

RAHM, D., KIRKLAND, J. \& BOZEMAN, B. 2000. University-Industry $R \& d$ Collaboration in the United States, the United Kingdom, and Japan, Kluwer Academic Publishers.

RAISCH, S. \& BIRKINSHAW, J. 2008. Organizational Ambidexterity: Antecedents, Outcomes, and Moderators. Journal of Management, 34, 375-409.

RASMUSSEN, E., MOSEY, S. \& WRIGHT, M. 2014. The influence of university departments on the evolution of entrepreneurial competencies in spin-off ventures. Research Policy, 43, 92-106.

RADOSEVICH, R., 1995. A model for entrepreneurial spin-offs from public technology sources. International Journal of Technology Management, 10(7-8), pp.879-893.

ROBINSON, S., LOCKETT, N., BICKNELL, A., FRANCIS-SMYTHE, J. \& ARTHUR, J. 2010. Knowledge transfer: de-constructing the entrepreneurial academic. International Journal of Entrepreneurial Behavior \& Research, 16, 485-501.

ROTHAERMEL, F. T., AGUNG, S. D. \& JIANG, L. 2007. University entrepreneurship: a taxonomy of the literature. Industrial and Corporate Change, 16, 691-791.

ROTHWELL, R. 1992. Successful industrial innovation: critical factors for the 1990s. $R \& D$ Management, 22, 221-240.

SCHARTINGER, D., RAMMER, C., FISCHER, M. \& FROHLICH, J. 2002. Knowledge interactions between universities and and industry in Austria: Sectoral patterns and determinants. Research Policy, 31.

SCHMOCH, U., LICHT, G. \& REINHARD, M. 2000. Wissens und Technologietransfer in Deutschland. Stuttgart 2000: Fraunhofer IRB Verlag.

SHARIFI, H. \& LIU, W. 2010. An Exploratory Study of Management of University Knowledge Transfer Offices in the UK. In: RESEARCH, A. I. O. M. (ed.) Academic Publications. London: Management School, University of Liverpool. 
Distinctions between Entrepreneurial Academic and Academic Entrepreneurs :

Accepted for Publication in the International Journal of Technology Management

SIEGEL, D. S., VEUGELERS, R. \& WRIGHT, M. 2007. Technology transfer offices and commercialization of university intellectual property: performance and policy implications. Oxford Review of Economic Policy, 23, 640-660.

SIEGEL, D. S., WALDMAN, D. \& LINK, A. 2003. Assessing the impact of organizational practices on the relative productivity of university technology transfer offices: an exploratory study. Research policy, 32, 27-48.

SIEGEL, D.S., WALDMAN, D.A., ATWATER, L.E. \& LINK, A.N., 2003b. Commercial knowledge transfers from universities to firms: improving the effectiveness of university-industry collaboration. The Journal of High Technology Management Research, 14, pp.111-133.

SLAUGHTER, S. \& LESLIE, L. 1997. Academic Capitalism: Politics, Policies, and the Entrepreneurial University, Baltimore, MD, The John Hopkins University Press.

SMALLBONE, D., KITCHING, JOHN, BLACKBURN, ROBERT, AND MOSAVI, SARA 2015. Anchor institutions and small firms in the UK: A review of literature on anchor institutions and their role in developing management and leadership skills in small firms. UK Commission for Employment and Skills.

SU, Z., AHLSTROM, D., LI, J. \& CHENG, D. 2013. Knowledge creation capability, absorptive capacity, and product innovativeness. R\&D Management, 43, 473-485.

TORNATZKY, L., WAUGAMAN, P. G. \& GRAY, D. O. 2002. Innovation U:New University Roles in a Knowledge Economy. In: COUNCIL, S. T. (ed.).

TRANFIELD, D., DENYER, D. \& SMART, P. 2003. Towards a methodology for developing evidence-informed management knowledge by means of systematic review. British Journal of Management, 14, 207-222.

VENKATARAMAN, N. \& TANRIVERDI, H. (eds.) 2004. Reflecting Knowledge in Strategy Research: Conceptual Issues and Methodological Challenges: Elsevier.

WILSON, T. 2012. A Review of Business-University Collaboration. In: DEPARTMENT FOR BUSINESS, I. S. (ed.). London.

WRIGHT, M. 2014. Academic entrepreneurship, technology transfer and society: where next? The Journal of Technology Transfer, 39, 322-334. 
Distinctions between Entrepreneurial Academic and Academic Entrepreneurs : Accepted for Publication in the International Journal of Technology Management

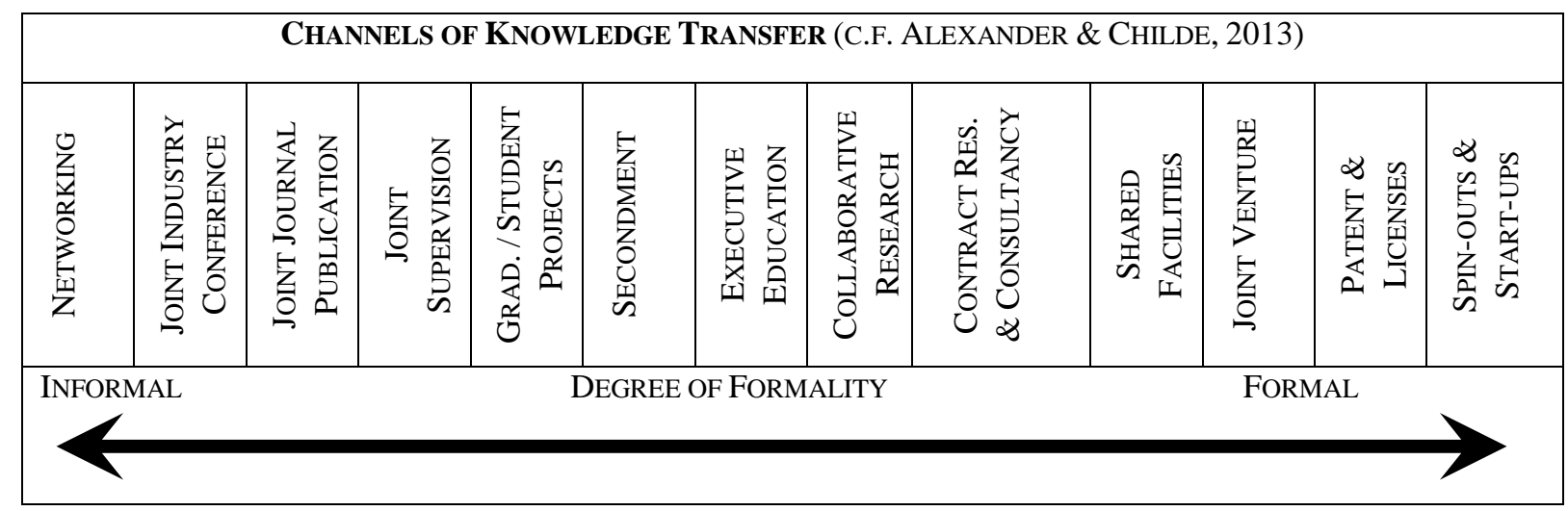


Distinctions between Entrepreneurial Academic and Academic Entrepreneurs : Accepted for Publication in the International Journal of Technology Management

SOFTER, MORE INFORMAL, RELATIONAL, PARTNERING-STYLE ENGAGEMENT UTILISED BY

\section{ENTREPRENEURIAL ACADEMICS}

Networking - groups of professionals and/or academics come together and meet face-to-face under a banner of common interest or subject discipline

Joint Conference - audience of company employees and academics. Speakers are taken from both groups.

Joint Journal Publications - academics and professionals develop a paper together into professional journals.

Joint Supervision - academics and industrialists come together to supervise a piece of research.

Student Placements / Graduate Employment - transfer of a graduate into a company partner.

Secondment - member of staff is present for a period of time in another organisation.

Executive Education- commercial partners keep their professional knowledge up to date with new developments delivered by academics.

Collaborative Research - commercial and academic partners agree to work together to discover new knowledge or to propose solutions solving a problem.
HARDER, MORE FORMAL, TRANSACTIONAL, CONTRACTING-STYLE ENGAGEMENT UTILISED BY ACADEMIC ENTREPRENEURS

\section{Contract Research \& Consultancy - a company} has a problem and wishes for either: a "known" solution to be applied to their problem (consultancy); an unknown solution to be researched and then presented to the company Shared Facilities - a university and a commercial partner join together to invest in the development and operation of a facility or piece of equipment.

Joint Ventures - rely on a set of legal agreements that ties a company partner and an academic with a common purpose without creating a new legal entity.

Patents and Licenses - a particular piece of knowledge or know-how is protected by either an academic partner or a commercial partner.

Spin-outs - University personnel join together with commercial partners to create a company.

Figure 1: Modes of Engagement relating to Entrepreneurial Academics and Academic Entrepreneurs 
Distinctions between Entrepreneurial Academic and Academic Entrepreneurs :

Accepted for Publication in the International Journal of Technology Management

Table 1 - Overview of entrepreneurial academic vs academic entrepreneurs

\begin{tabular}{|l|l|l|}
\hline $\begin{array}{l}\text { Systematic Literature } \\
\text { Review Themes }\end{array}$ & \multicolumn{1}{|c|}{ Entrepreneurial Academic (EA) } & \multicolumn{1}{|c|}{ Academic Entrepreneur (AE) } \\
\hline Definitions & $\begin{array}{l}\text { "An academic faculty member who adopts an } \\
\text { entrepreneurial outlook, seeking opportunities to } \\
\text { supports their research objectives by engaging } \\
\text { with commercial partners in a range of } \\
\text { collaborative and less formal modes of } \\
\text { engagement" (Adapted from Meyer, 2003; } \\
\text { Duberley et al., 2007; Martinelli et al., 2008; } \\
\text { Perkmann et al., 2013; Alexander et al., 2015) }\end{array}$ & $\begin{array}{l}\text { "An academic faculty member who undertakes } \\
\text { modes of engagement, that capitalise on specific } \\
\text { market opportunities" (Adapted from Rothaermel } \\
\text { et al., 2007; Grimaldi et al., 2011). }\end{array}$ \\
\hline $\begin{array}{l}\text { Knowledge Transfer } \\
\text { Channels }\end{array}$ & $\begin{array}{l}\text { Engage in wider forms of knowledge transfer } \\
\text { which involves personal interactions with } \\
\text { industry (Duberley et al., 2007; Alexander et al., } \\
\text { 2015) }\end{array}$ & $\begin{array}{l}\text { Engage in activities which often lead to the } \\
\text { commercialisation of technology (Rothaermel et } \\
\text { al., 2007; Wright, 2014) }\end{array}$ \\
$\begin{array}{l}\text { 1) Networking (Link et al., 2007; D'Este and } \\
\text { Patel, 2007) } \\
\text { 2) Joint Industry Conference (D'Este and Patel, } \\
\text { 2007) }\end{array}$ & $\begin{array}{l}\text { 1) Contract Research and Consultancy (D'Este } \\
\text { and Patel, 2007; Perkmann and Walsh, 2007) }\end{array}$ \\
2) Shared Facilities (Alexander and Martin, 2013) \\
\hline
\end{tabular}


Distinctions between Entrepreneurial Academic and Academic Entrepreneurs : Accepted for Publication in the International Journal of Technology Management

\begin{tabular}{|l|l|l|}
\hline & $\begin{array}{l}\text { 3) Joint Journal Publication D'Este and Patel, } \\
\text { 2007; Link et al., 2007) }\end{array}$ & $\begin{array}{l}\text { 4) Patents \& Licences (Fini et al., 2010; D'Este } \\
\text { and Patel, 2007) }\end{array}$ \\
& $\begin{array}{l}\text { 4) Joint Supervision (Alexander and Martin, 2013; } \\
\text { D'Este and Patel, 2007) } \\
\text { 5) Grad./Student Projects (Alexander and Childe, } \\
\text { 2012) Spin-outs and start-ups (Fini et al., 2010; Ding } \\
\text { and Choi, 2011) }\end{array}$ \\
& $\begin{array}{l}\text { 6) Secondment (Perkmann and Walsh, 2007; } \\
\text { Alexander and Martin, 2013) } \\
\text { 7) Executive Education (Libaers, D. and Wang, } \\
\text { T., 2012) } \\
\text { 8) Collaborative research (Perkmann and Walsh, } \\
\text { 2007; Alexander and Martin, 2013) }\end{array}$ \\
\hline
\end{tabular}


Distinctions between Entrepreneurial Academic and Academic Entrepreneurs : Accepted for Publication in the International Journal of Technology Management

\begin{tabular}{|c|c|c|}
\hline Motivations & $\begin{array}{l}\text { - Furthering research objectives (D'este and } \\
\text { Patel, 2007; Alexander et al., 2015) } \\
\text { - Gaining feedback on validity/appropriateness } \\
\text { (Robinson et al., 2010; Alexander et al., 2015) } \\
\text { - } \text { Academic esteem with peers (D'este and } \\
\text { Patel, 2007; Cunningham et al., 2016a) } \\
\text { - Academic contribution to the field (D'este } \\
\text { - } \text { and Patel, 2007; Cunningham et al., 2016a) } \\
\text { - } \text { Alexander et al., 2015) } \\
\text { Institutional Income (Alexander et al., 2015; } \\
\text { Cunningham et al. , 2016a) }\end{array}$ & $\begin{array}{l}\text { - Understanding lifecycle/adoption of research } \\
\text { (Meyer, 2003; Perkmann et al., 2013) } \\
\text { - Public recognition (Meyer, 2003; Perkmann et } \\
\text { al., 2013) } \\
\text { - Private Income (Perkmann and Walsh, 2007, } \\
\text { Lam, 2011) }\end{array}$ \\
\hline
\end{tabular}


Distinctions between Entrepreneurial Academic and Academic Entrepreneurs : Accepted for Publication in the International Journal of Technology Management

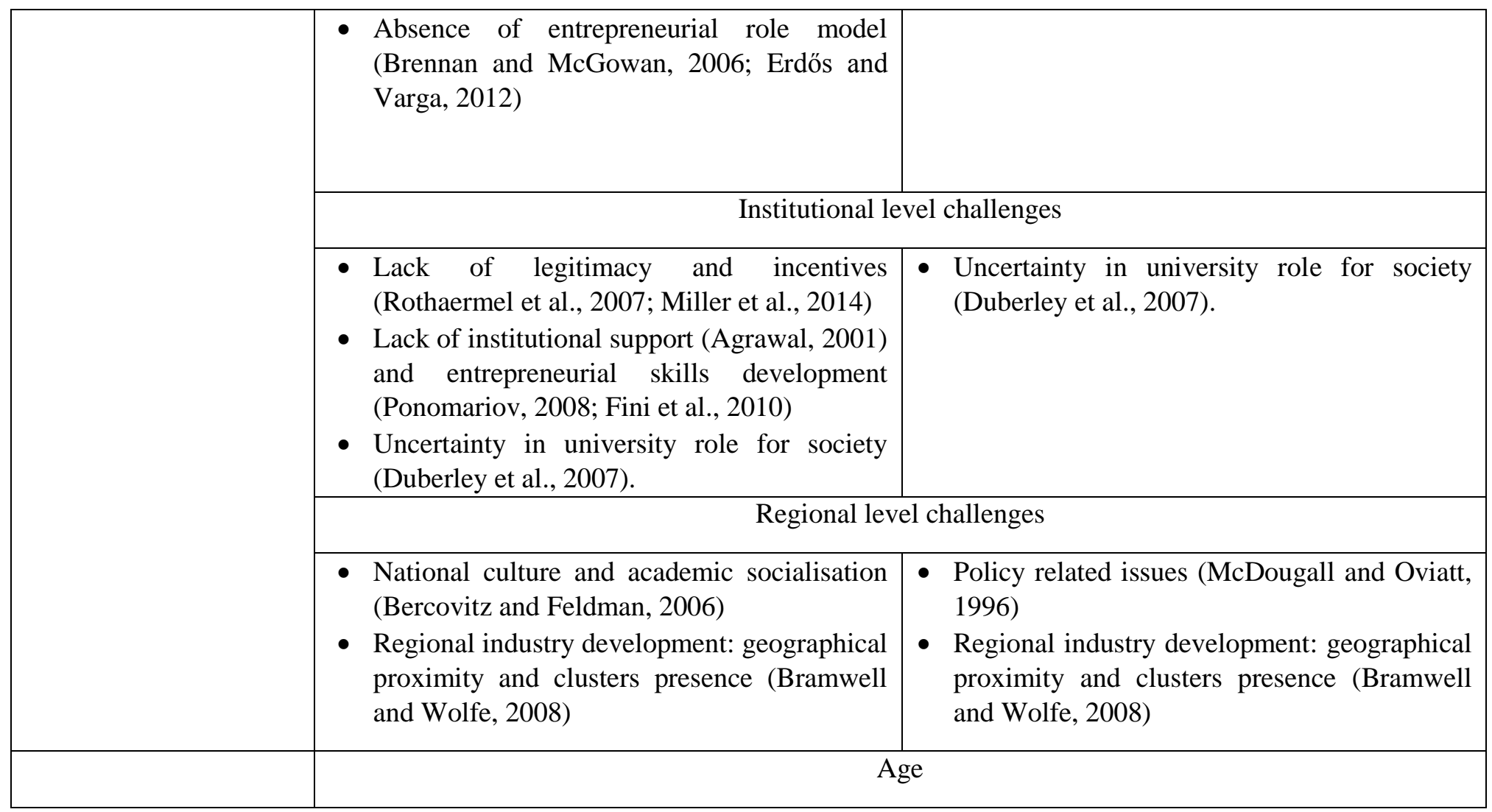


Distinctions between Entrepreneurial Academic and Academic Entrepreneurs : Accepted for Publication in the International Journal of Technology Management

\begin{tabular}{|c|c|}
\hline \multirow{5}{*}{$\begin{array}{l}\text { Supplementary factors } \\
\text { and determinants }\end{array}$} & $\begin{array}{l}\text { - Seniority was identified as a factor determining industrial engagement but this was not different } \\
\text { when comparing AE and EA (Perkmann et al, 2013) } \\
\text { - Social capital was identified as being a contributory factor but this was not different when } \\
\text { comparing AE and EA (Aldridge and Audretsch, 2011) }\end{array}$ \\
\hline & Prior Experience \\
\hline & $\begin{array}{l}\text { - Length of prior experience was identified as being a contributing factor to engagement, with more } \\
\text { mature researchers being more likely to engage with business but this was not different when } \\
\text { comparing AE with EA (D'Este and Patel, 2007) }\end{array}$ \\
\hline & Gender \\
\hline & $\begin{array}{l}\text { - Being Male was considered a factor that influenced the likelihood of engagement but this was } \\
\text { not altered when considering AE and EA (Abreu and Grinevich, 2013, Guerrero et al., 2015, } \\
\text { Perkmann et al., 2013) }\end{array}$ \\
\hline
\end{tabular}


Distinctions between Entrepreneurial Academic and Academic Entrepreneurs : Accepted for Publication in the International Journal of Technology Management

Table 2: Future Research Directions

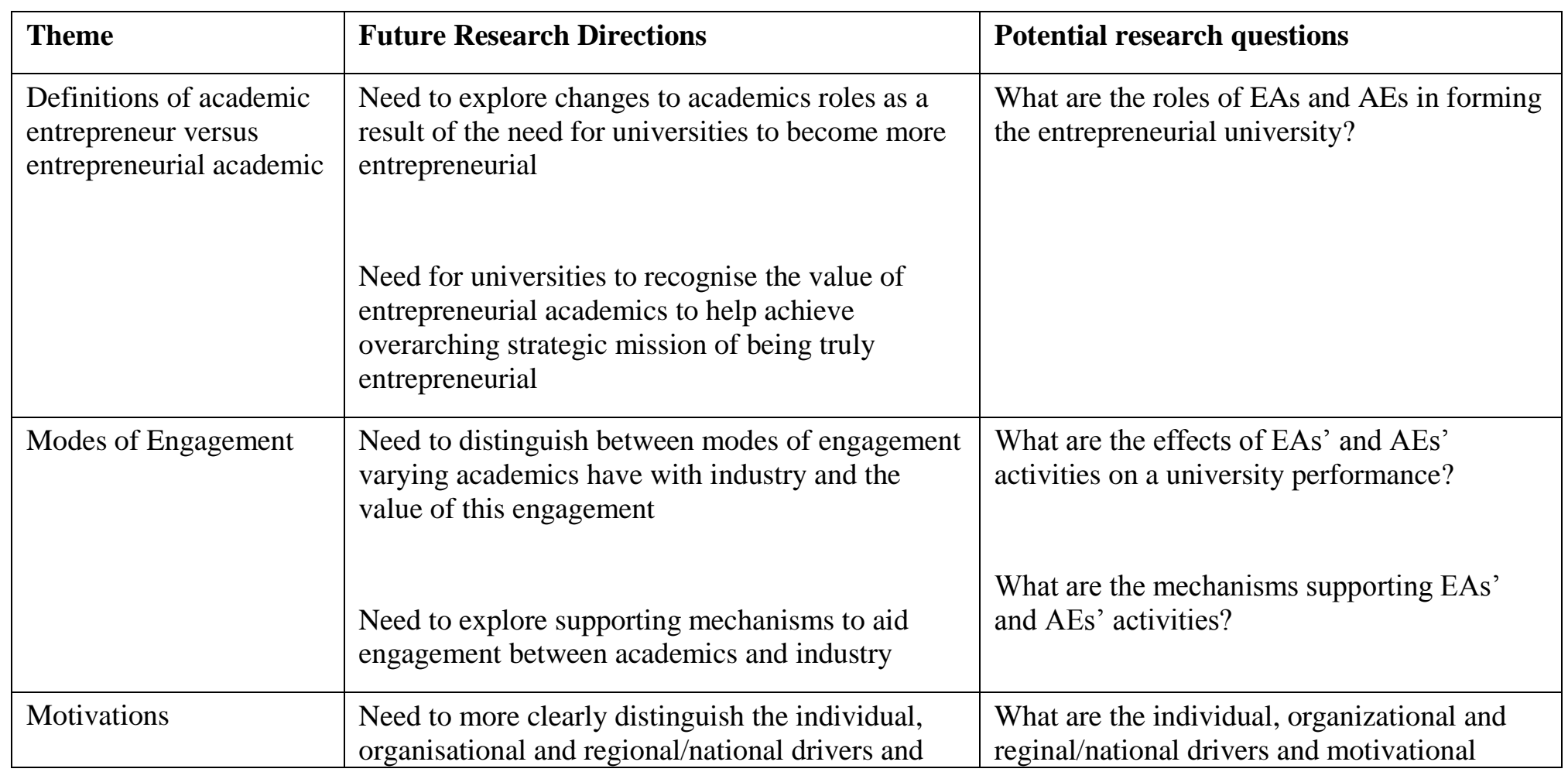


Distinctions between Entrepreneurial Academic and Academic Entrepreneurs : Accepted for Publication in the International Journal of Technology Management

\begin{tabular}{|c|c|c|}
\hline & $\begin{array}{l}\text { motivational factors to become an entrepreneurial } \\
\text { academic }\end{array}$ & $\begin{array}{l}\text { factors to become an entrepreneurial } \\
\text { academic? }\end{array}$ \\
\hline $\begin{array}{l}\text { Challenges and } \\
\text { supplementary factors }\end{array}$ & $\begin{array}{l}\text { Need for entrepreneurship training for junior and } \\
\text { female academics } \\
\text { Need to explore the impact of boundary spanners } \\
\text { and role models on entrepreneurial behaviour } \\
\text { Need for university reward and performance } \\
\text { mechanisms to recognise the value of less formal } \\
\text { collaboration activities }\end{array}$ & $\begin{array}{l}\text { How can you measure the value and impact of } \\
\text { less formal collaboration activities? } \\
\text { What impact do entrepreneurial academics } \\
\text { have on society? } \\
\text { How can universities stimulate entrepreneurial } \\
\text { activities amongst junior and female } \\
\text { academics? } \\
\text { What specific challenges exist for female } \\
\text { academics who want to be entrepreneurial? } \\
\text { How can boundary spanners and role models } \\
\text { aid university-industry knowledge transfer? } \\
\text { What are the micro-social factors affecting } \\
\text { academics' engagements with industry? How } \\
\text { do these factors affect academics' behaviour? } \\
\text { What incentives and performance mechanisms } \\
\text { are attractive to EAs and AEs? } \\
\text { What are the meso- and macro-level factors } \\
\text { affecting academics' engagements with }\end{array}$ \\
\hline
\end{tabular}


Distinctions between Entrepreneurial Academic and Academic Entrepreneurs : Accepted for Publication in the International Journal of Technology Management

\begin{tabular}{|l|l|l|}
\hline & $\begin{array}{l}\text { Need to explore how both institutional and } \\
\text { departmental culture restrains or encourages } \\
\text { entrepreneurial behaviour }\end{array}$ & $\begin{array}{l}\text { industry? How do these factors affect } \\
\text { academics' behaviour? } \\
\text { Need to explore academic identity when faced } \\
\text { with changing expectations }\end{array}$ \\
$\begin{array}{l}\text { Need to explore how norms regarding academic- } \\
\text { industry engagement activities varies between } \\
\text { universities of different types and within different } \\
\text { regions. }\end{array}$ & to be an AE or EA? \\
\hline
\end{tabular}


Distinctions between Entrepreneurial Academic and Academic Entrepreneurs : Accepted for Publication in the International Journal of Technology Management

Appendix 1: Journals Selected for Review

\begin{tabular}{|c|l|}
\hline Journal Discipline & \multicolumn{1}{|c|}{ Journal Names } \\
\hline Entrepreneurship & Entrepreneurship and Regional Development \\
& Entrepreneurship, Theory and practice \\
& International Journal Entrepreneurial Behaviour and \\
& Research \\
& Journal of business venturing \\
& Journal of Small Business Management \\
& Small Business Economics \\
& Strategy Entrepreneurship Journal \\
\hline Higher Education & Academy of Management Learning and Education \\
& Industry and Higher Education \\
& Management Learning \\
& Studies in Higher Education \\
\hline Innovation & International Journal of Technology Management \\
& Journal of Production and Innovation Management (JPIM) \\
& Journal of Technology Transfer \\
& R\&D Management \\
& Research Policy \\
& Technovation \\
\hline
\end{tabular}


Distinctions between Entrepreneurial Academic and Academic Entrepreneurs : Accepted for Publication in the International Journal of Technology Management

\section{Appendix 2: Systematic Literature Review Proforma and Entry Samples}

\begin{tabular}{|c|c|c|c|}
\hline Data FieldVEntry sample & Sample 1 & Sample 2 & Sample 3 \\
\hline Authors & $\begin{array}{l}\text { Allen, S. D., Link, A. N., \& } \\
\text { Rosenbaum, D. T }\end{array}$ & $\begin{array}{l}\text { Chrisman, J. J., Hynes, T., \& } \\
\text { Fraser, S. }\end{array}$ & Rosa, P., \& Dawson, A. \\
\hline Year & 2007 & 1995 & 2006 \\
\hline Article Title & $\begin{array}{l}\text { Entrepreneurship and human } \\
\text { capital: Evidence of patenting } \\
\text { activity from the academic sector. }\end{array}$ & $\begin{array}{l}\text { Faculty entrepreneurship and } \\
\text { economic development: The case } \\
\text { of the University of Calgary }\end{array}$ & $\begin{array}{l}\text { Gender and the commercialization } \\
\text { of university science: academic } \\
\text { founders of spinout companies }\end{array}$ \\
\hline Research Question Focus & $\begin{array}{l}\text { Link between academic human } \\
\text { capital (tenure track, age, gender) } \\
\text { and patenting jointly with industry. }\end{array}$ & $\begin{array}{l}\text { University and its budgetary } \\
\text { problems - impact on faculty } \\
\text { entrepreneurial activities }\end{array}$ & $\begin{array}{l}\text { Influence of gender on academic } \\
\text { entrepreneurship }\end{array}$ \\
\hline $\begin{array}{l}\text { Theoretical lens/ theories } \\
\text { underpinning research }\end{array}$ & $\begin{array}{l}\text { Human capital theory, technology } \\
\text { transfer literature }\end{array}$ & $\begin{array}{l}\text { University entrepreneurship } \\
\text { literature }\end{array}$ & $\begin{array}{l}\text { Human capital theory, Sociological } \\
\text { gender theory, feminist theories, } \\
\text { Attribution and locus of control } \\
\text { theory }\end{array}$ \\
\hline Unit of analysis & $\begin{array}{l}\text { Individual (university scientists } \\
\text { and engineers) }\end{array}$ & Business venture & Individual \\
\hline
\end{tabular}


Distinctions between Entrepreneurial Academic and Academic Entrepreneurs : Accepted for Publication in the International Journal of Technology Management

\begin{tabular}{|c|c|c|c|}
\hline Sampling Method & Stratified sampling & $\begin{array}{l}\text { Non-probability purposive } \\
\text { sampling }\end{array}$ & $\begin{array}{l}\text { Non-probablility purposive } \\
\text { sampling }\end{array}$ \\
\hline Sample size & 4800 & 1335 & 40 \\
\hline $\begin{array}{l}\text { Measure (interviews, } \\
\text { questionnaires etc.) }\end{array}$ & Questionnaire & Questionnaire, interviews & $\begin{array}{l}\text { Questionnaire, interviews, } \\
\text { secondary data }\end{array}$ \\
\hline Country & USA & Canada & UK \\
\hline University type & Research-led & Research-led & Research-led \\
\hline Faculty type & $\begin{array}{l}12 \text { science and technology } \\
\text { disciplines }\end{array}$ & $\begin{array}{l}\text { Engineering, Environmental } \\
\text { Design, Management, Medicine, } \\
\text { and Science }\end{array}$ & Various \\
\hline Key Findings & $\begin{array}{l}\text { 1) faculty with tenure are more } \\
\text { likely to engage in such activity 2) } \\
\text { older faculty are more likely to } \\
\text { engage with industry, to a point, } \\
\text { holding tenure constant } 3 \text { ) male } \\
\text { faculty are more likely to patent } \\
\text { with industry than female faculty }\end{array}$ & $\begin{array}{l}\text { 1) call for reward mechanisms for } \\
\text { faculty engaged in research with } \\
\text { commercial potential 2) Need in } \\
\text { closer ties between members of } \\
\text { Engineering, Sciences, and } \\
\text { Medical Faculties and the } \\
\text { Management Faculty via joint } \\
\text { educational and research programs } \\
\text { 3) the government should begin to } \\
\text { look at universities more as } \\
\text { businesses }\end{array}$ & $\begin{array}{l}\text { 1) Owing to the low number of } \\
\text { women in senior research positions } \\
\text { in many leading science } \\
\text { departments, few women had the } \\
\text { chances to lead a spinout. 2) both } \\
\text { male and female science } \\
\text { entrepreneurs displayed similar } \\
\text { motivations to entrepreneurship, } \\
\text { but collectively as scientists } \\
\text { differed appreciably from non- } \\
\text { academic entrepreneurs. 3) Women } \\
\text { science entrepreneurs faced some } \\
\text { additional problems in areas such } \\
\text { as the conflict between work and } \\
\text { home life and networks. }\end{array}$ \\
\hline
\end{tabular}


Distinctions between Entrepreneurial Academic and Academic Entrepreneurs : Accepted for Publication in the International Journal of Technology Management

\begin{tabular}{|c|c|c|c|}
\hline Areas for future research & $\begin{array}{l}\text { 1) Additional research on the } \\
\text { managerial and economic impacts } \\
\text { of tenure } 2 \text { ) whether the quality of } \\
\text { faculty research and teaching } \\
\text { changes with the award of lifetime } \\
\text { employment } 3 \text { ) do faculty —once } \\
\text { receiving tenure- begin to seek to } \\
\text { supplement their salaries either } \\
\text { through patenting activities or } \\
\text { consulting activities. }\end{array}$ & $\begin{array}{l}\text { 1) the possibility of economic } \\
\text { development activities in other } \\
\text { Faculties (Social Sciences, } \\
\text { Education, and Fine Arts) }\end{array}$ & $\begin{array}{l}\text { 1) Do different types of science } \\
\text { (e.g. medical, SET, Social Science) } \\
\text { produce different types of } \\
\text { commercialization and spinoffs 2) } \\
\text { research is needed on a wider } \\
\text { sample to assess more closely how } \\
\text { the conflicts of career breaks } \\
\text { operate in practice } 3 \text { ) How far } \\
\text { participation in entrepreneurship, } \\
\text { seniority and gender interact in } \\
\text { different subject areas? }\end{array}$ \\
\hline
\end{tabular}


Distinctions between Entrepreneurial Academic and Academic Entrepreneurs : Accepted for Publication in the International Journal of Technology Management 